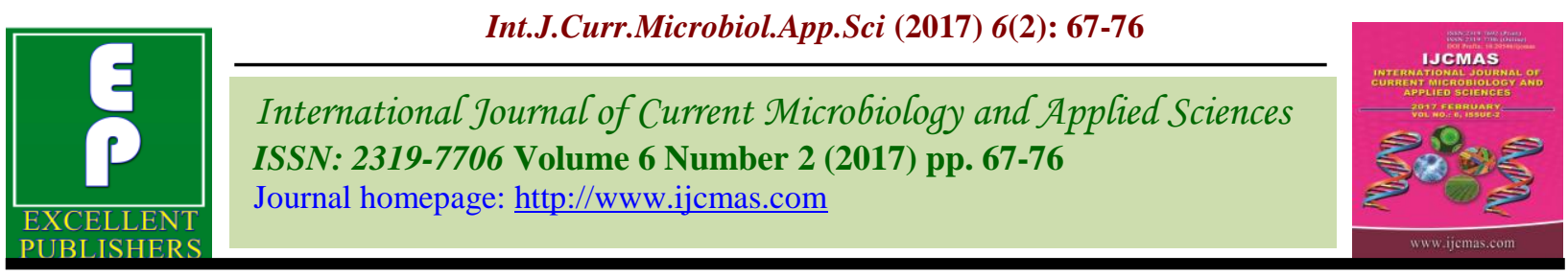

Original Research Article

http://dx.doi.org/10.20546/ijcmas.2017.602.009

\title{
Microbial Diversity in the Rhizosphere of Momordica charantia $L$. (Bitter Gourd)
}

\author{
Ritu Singh, Ajay Kumar, Monika Singh, Satyendra Kumar Maurya \\ and K.D Pandey*
}

\begin{abstract}
Centre of Advance Study in Botany, Institute of Science, Banaras Hindu University,
Varanasi- 221005, India

*Corresponding author
\end{abstract}

\section{A B S T R A C T}

Keywords

Momordica

charantia,

Rhizosphere, Root

transect, Bacteria,

Actinomycetes.

\section{Article Info}

Accepted:

05 January 2017

Available Online:

10 February 2017
The rhizosphere of Momordica charantia (Bitter gourd) has a significant effect on the aerobic bacteria, anaerobic bacteria and actinomycetes population compared to the respective barren soil. Rhizospheric soils $(0-25 \mathrm{~cm}$ depth) along the roots were processed at surface $(0-1 \mathrm{~cm})$ and also at $5 \mathrm{~cm}$ interval in the spring season. Bacterial population significantly differed in each transect with a maximum at 1-5 $\mathrm{cm}$ depth, and decreased with the increase in the root length. Rhizosheric region $(20-25 \mathrm{~cm})$ exhibited maximum R/S ratio (rhizospheric effect). Microbial population differed significantly season wise in rhizosphere and barren soil. The maximal number of anaerobic bacteria was during rainy season. Rhizosphere was maximally colonized by bacteria at the flowering and fruiting stage. Root border cells released in highest number in the $5 \mathrm{~cm}$ root length during seedling growth.

\section{Introduction}

Soil is considered as the store house of microbial activity, though the microorganisms occupy less than five percent space. Root exudes organic carbon which is main source of food and microbial activity in the rhizosphere. Microbial population in the rhizosphere remains one to two order magnitude higher compared to bulk soil (Curl and Truelov, 1986; Ambardar and Vakhlu et al., 2013). Diversity and community structure of microorganisms in the rhizosphere are influenced both by plant and soil type (Latour et al., 1996). Plant root-microbe interaction can influence plant growth and nutrient dynamics and help the plant to alter the susceptibility to diseases and abiotic stress (Bakker et al., 2013; Glick, 2014). Microbial population in rhizosphere remains one to two order magnitude greater compared to barren soils (Curl and Truelove, 1986). The rhizospheric effect on the soil microbial population can be assessed by comparing the population between the rhizosphere $(\mathrm{R})$ and the barren soil $(\mathrm{S})$, the " $\mathrm{R} / \mathrm{S}$ " ratio (Atlas and Bertha, 2000).

The structure and function of microbial community inhabiting rhizosphere depends on the age of plant, root morphology and plant root - soil interaction (Marschner et al., 
2002). Studies to the effect of seasons on microbial activity and biomass of surface soils are contradictory (Blume et al., 2002). Actinomycetes, the important rhizosphere inhabitants of plants, enhance plant growth and protect plant roots against phytopathogens (Doumbou et al., 2002). Anaerobic bacteria generally develop at the expense of root exudates, decomposition or cellular autolysis and the aspect seems to have received little attention of investigators.

From the foregoing, it seems imperative to investigate the rhizospheric microorganisms of important plants related to human nutrition and health. How the microorganisms differ with the change in the climate (seasons), the stages of growth and also at different depths along the rhizosphere in the sub surface soil, was the main objective of the present study. The plant selected Momordica charantia, is a cosmopolitan vegetable crop in India and of the world, and also important medicinally as the fruits are used to cure diabetes.

\section{Materials and Methods}

\section{Site and soil sampling}

The study was conducted at Botanical Garden, $\left(20^{\circ} 18^{\prime} \mathrm{N}\right.$ and $80^{\circ} 36^{\prime} \mathrm{E}$, elevation $80.71 \mathrm{~m})$, Banaras Hindu University, Varanasi. Soil collected from garden, was sieved (2 $\mathrm{mm}$ sieve) after removing the debris, roots and litter. The fine soil mixed with manure and sand (2:1:1) was poured into earthen pots to support plant growth. The soil was subsequently collected from the pots at the flowering stage of plant unless mentioned otherwise.

\section{Physicochemical properties of soil}

Soil moisture was analyzed during different seasons by drying the fresh soil to a constant weight at $80^{\circ} \mathrm{C}$. Total organic carbon and $\mathrm{N}$ was determined by method described by Jackson (1967).

\section{Growth conditions}

Experiments were performed in sets depending on the requirement. The surface sterilized and unsterilized seeds were sown on the Luria nutrient agar medium to look for the microflora associated with spermosphere.

In the second set of experiments, bitter melon seeds were sown into each pot containing soil mixture and plants grown under natural environment of the Botanical garden, where soil water level was kept nearly constant by watering every $3^{\text {rd }}$ day.

To observe the seasonal variations in microbial population, the seeds were sown in mid February for spring season, mid April for summer season and mid July for rainy season, respectively. Bitter gourd is a 120 days crop, seeds germinate on the third day after sowing (DAS), flowering occurs after 40 days and fruiting stage lasts 90 days. Aerobic bacterial population at different rhizosphere depths was estimated at the flowering stage.

\section{Sampling of rhizosphere and barren soil}

The soils adhering to the root of bitter gourd at the flowering stage in the spring, summer and rainy seasons (about $5 \mathrm{~mm}$ radius outside the root) were collected gently, immediately transferred to sterilized polythene bags (medium density) and brought to the laboratory. The clods were gently removed and the root adhering soil collected on the Whatman filter paper no. 1. After weighing, suitable dilutions $\left(10^{-5} ; 10^{-6}\right)$ of soil were made with pre-sterilized phosphate buffer (0.01M, pH 7.0). Soil in the botanical garden that did not support any plant growth was taken as the barren soil (control) 


\section{Enumeration of bacterial population}

Total aerobic and anaerobic bacteria population was detected by cultivation method using two sets of Luria nutrient agar petri dishes whereas actinomycetes number was detected on starch casein nutrient agar.

The standard plate counts (SPC) method was employed to determine culturable population of microorganism in the rhizosphere of bitter gourd and barren soil. Total culturable bacteria population was determined on Luria nutrient agar using $0.1 \mathrm{ml}$ inoculum $\left(10^{-5}\right.$ and $10^{-6}$ dilution), while actinomycetes population was determined, from $10^{-3}$ and $10^{-4}$ soil dilution on starch casein agar plates. The anaerobic bacteria population was determined by incubating the inoculated petri dishes in anaerobic jar with air replaced by Argon, $\mathrm{N}_{2}$ and $\mathrm{CO}_{2}\left(\mathrm{Ar}: \mathrm{N}_{2}: \mathrm{CO}_{2} ; 75: 21: 4 \% \mathrm{v} / \mathrm{v}\right)$. Plates were incubated $(72 \mathrm{~h})$ at $30^{\circ} \mathrm{C}$ for bacteria, and $14 \mathrm{~d}\left(37^{\circ} \mathrm{C}\right)$ for actinomycetes. Colonies were counted at the pin head stage through a colony counter.

To observe the number of root associated bacteria at different depth, the roots with the rhizosphere soil were divided and cut into five different zones: $0-1,1-5,5-10,10-15,15-20$ and $20-25 \mathrm{~cm}$ along root length from the soil surface towards root tip. To obtain the rhizosphere sample from each zone, 10 root segments were used. From the last zone (20$25 \mathrm{~cm}$ from the root tip) 10 to 15 root tips were used to procure the sufficient rhizosphere soil.

\section{Enumeration of root border cells}

Bitter gourd seeds were surface sterilized with ethanol (70\%) and mercuric chloride $(0.2 \%)$. The seeds were sown on to Murashige and Skoog medium (Murashige and Skoog, 1962) containing $1.25 \%$ agarose supplemented with $2.5 \%$ sucrose. Plants were grown in vertically oriented petri dishes under continuous light (intensity $60 \mu \mathrm{Em}^{-2} \mathrm{~s}^{-2}$ ) in the cabinet at $30 \pm$ $2^{\circ} \mathrm{C}$. Root cap and border cells were harvested from 1- 15 seedlings. Root tips were placed in water and gently vortexed to release the root border cells and counted on a haemocytometer. Each value represents the average of at least five roots for each day (Canneson et al., 2011). Cells were stained with aqueous toluidine blue stain.

\section{Statistical analysis}

The data were analyzed by using software SPSS version 16.0 software and plotted by Sigma plot 8.0.

\section{Results and Discussion}

Plant roots exude an array of chemical, carbon containing metabolites in the soil matrix results into rhizodeposition. The root interacts number of microorganisms in the rhizosphere of the plants and the microorganisms and their product also interact plant roots in positive, negative and neutral ways. Rhizodeposition includes root border cell exudation, secretion, leakage of sugars, organic acids and amino acids (Oku et al., 2012) hormones, phenolics and sugar phosphate esters (Doornbos et al., 2012). The rhizospheric bacteria possess quorum sensing, small diffusible molecules, help in the exchange of the cell to cell communication between each other (Perez- Montano et al., 2014)

Data presented in table 1 revealed that both positive and negative correlation existed between microbial population, $\mathrm{C} / \mathrm{N}$ ratio and the moisture content. The bacterial population differed significantly during the seasons in the rhizosphere and also in the barren soil. Figure 1 A reveals that rhizosphere soil had its own effect on the total aerobic bacteria population. In the barren soil, the population was low 
with respect to different seasons (Figure1B). The spring season supported the maximum population and the same was minimal in the rainy season. The $\mathrm{R} / \mathrm{S}$ ratio of aerobic bacteria was high in summer season (Figure 1C). Also, the cultivation based microbial analysis of total aerobic bacteria, anaerobic bacteria and actinomycetes counts was significantly high within the three seasons in the rhizosphere, indicating shifts of the relative abundance in the soil due to the rhizosphere effect.

Anaerobic bacteria population was also high in rhizosphere over the barren soil (Figures1A and 1B). Rainy season supported higher bacterial population than either summer or spring. Actinomycetes present in bitter gourd soil during different seasons were significantly high in the rhizosphere soil (Figure 1A) than barren soil (Figure 1B), and maximum was during the spring season, Thus seasons seem to have a significant effect on the culturable microbial population (Analysis of variance, $\mathrm{P}<0.05$ ).

Higher population of total aerobic bacteria, anaerobic bacteria and actinomycetes in bitter gourd rhizosphere in comparison to the barren soil was similar to the other reports (Brimecombe et al., 2001; Karthikeyan et al., 2008), and can be explained by the $\mathrm{C} / \mathrm{N}$ ratio which was positively correlated with the population as the carbon substrate of the root exudates favoured the microbial colonization in the rhizosphere. A high degree of carbon decomposition is reported to occur under aerobic conditions (Atlas and Bertha, 2000). At the higher $\mathrm{C} / \mathrm{N}$ ratio, the net immobilization of $\mathrm{N}$-compound occurs, and if the $\mathrm{C} / \mathrm{N}$ ratio is less, the net mineralization of ammonium occurs (Maier et al., 2009). The nitrate uptake by the root indirectly influences the root health and also the root exudates. Although the rate of mineralization resulted in lower $\mathrm{C} / \mathrm{N}$ ratio during summer, it offered inductive conditions for the plant growth but the high temperature and low moisture level created a stressful environment for the plant vigor and health.

The rhizosphere effect has been reported in various studies as the input of organic matter derived from the root exudates played a major role (Smalla et al., 2001). The total aerobic bacteria count was highest because the root growth had achieved its maximum length during March, and the organic compounds released from the roots into the soil, resulted in the concomitant abundance of copiotrophic organisms, that are able to grow in nutrient rich environment (Gonzalez- Franco et al., 2009).

The highest number of anaerobic bacteria during rainy season could be explained on the basis of moisture content that was highest and almost saturated. Besides, the inter-aggregate and intra- aggregates pore were also minimal in number and size due to frequent rains. The low availability of air and free oxygen during the rainy season could have created a favourable condition for the growth of facultative/ obligate anaerobes. The hypothesis behind the maximum population of actinomycetes in the spring is attributed to the nutrient rich conditions, favourable temperature, moisture and aerobic soil condition.

\section{Aerobic bacterial population in rhizosphere at different ages of the plant growth}

Figure 2 revealed that bacterial population in rhizospheric soil collected at the different plant age increased from spermosphere with the plant age. Flowering stage supported the maximum bacterial population in the rhizosphere. There was a slight decrease during the maximum flowering to fruiting stage, and a sharp decrease in the population was noticed during the old and senescence stage of plant. 
A strong effect of plant growth stages on the bacterial communities associated with bitter gourd appears to be the effect of soil-plantmicrobe interaction. About five percent (Walker et al., 2003) to 60\% (Marschner et al., 2001) of photosynthetic carbon fixed by the plant can be transferred to the rhizosphere by exudation through the roots. The maximum microbial population at the flowering stage might be due to carbon compounds deposited in the soil possibly through the continuous programmed cell death of root cap and root border cells (Odell et al., 2008; Weinert et al., 2009).

\section{Bacterial population of rhizosphere and barren soil at different root zone}

The results revealed that the maximum bacterial population was in $1-5 \mathrm{~cm}$ in rhizospheric zone which was also applicable to the barren soil (Figure 3A). The bacterial population decreased significantly along the length of the root thereafter. Population differed significantly in both the soil types with respect to the distance from the root surface. Though the rhizospheric effect decreased from surface to $10 \mathrm{~cm}$ soil depth, a sudden and sharp increase at the depth further was noticed in the soil zone of the root tip (10- $25 \mathrm{~cm})$ (Figure 3B).

The cluster analysis of rhizospheric bacterial population revealed that transect $0-1 \mathrm{~cm}$ and $5-10 \mathrm{~cm}$ formed a single cluster. All the other transects formed separate cluster (Figure 4), though 15- 20 and $20-25 \mathrm{~cm}$ transect were closely related. The culturable population indicated a significant difference $(P<0.05)$ at each depth intervals (transect) in the rhizosphere (Table 1).

A semi-quantitative estimation of root border cells revealed that a root length up to $5 \mathrm{~cm}$ length released maximum root border cells followed thereafter by a decline (Figure 5).
In the surface soil, the bacterial population remained low relative to the subsurface soils attributed to the production of certain toxic compounds during the decomposition of litter on the soil surface (Dutta and Agrawal, 2001).

The maximum population of bacteria occurred at the $5-10 \mathrm{~cm}$ depth and there was a gradual decrease in the vertical profile up to $40-60 \mathrm{~cm}$ followed by a slow decrease up to $90 \mathrm{~cm}$ and the population stabilized with respect to further subsurface vertical profile (Shukla, 2009).

One of the major objectives of the study was to investigate the distribution of bacterial population along root zones. The unequal distribution of bacteria at different transect was influenced by the two factors: a) the physicochemical characteristics of the soil as the vertical profile, and b) the rhizospheric effect. Although population decreased at the higher depth, the higher R/S ratio seemed to have supported the higher population size in the root cap region and the adjacent area. It is known that the root cap cells and the root border cells shed off regularly in this zone, and this was responsible for the higher nutrients released following their death and decay.

Root border cells play important role in the rhizosphere environment by promoting the growth of certain microorganisms and also the antimicrobial activity against some common pathogens (Wen et al., 2007; Cannesan et al., 2011). The number of border cells released depends on the plant species (Hamamoto et al., 2006). Although we have not measured the root border cell sloughed in a older roots of $25 \mathrm{~cm}$ length, it seems that the root cap region and the adjacent area (0- 5 $\mathrm{cm})$ released the root border cells regularly in this zone, and this could be responsible for the high nutrient release following their death and decay. 
Table.1 Pearson correlation coefficients for different soil properties and microbial population

\begin{tabular}{lllll}
\hline Soil properties & $\mathrm{C} / \mathrm{N}$ & Total bacteria & Anaerobic bacteria & Actinomycetes \\
\hline Moisture $\%$ & $0.821^{* *}$ & -0.151 & $0.535^{*}$ & $-0.500^{*}$ \\
Sig. & $(0.001)$ & $(0.550)$ & $(0.035)$ & $(0.022)$ \\
C/N ratio & & 0.282 & $.863^{* *}$ & -0.96 \\
Sig. & & $(0.257)$ & $(0.001)$ & $(0.704)$ \\
\hline
\end{tabular}

Significance level $* * \mathrm{P}<0.01, * \mathrm{P}<0.05$

Fig.1 Influence of seasons on total aerobic, anaerobic bacteria and actinomycetes population in the rhizosphere (A), barren soil (B) and R/ S ratio (C). Letters on the bar represents significance based on Tukey HSD. P< 0.05

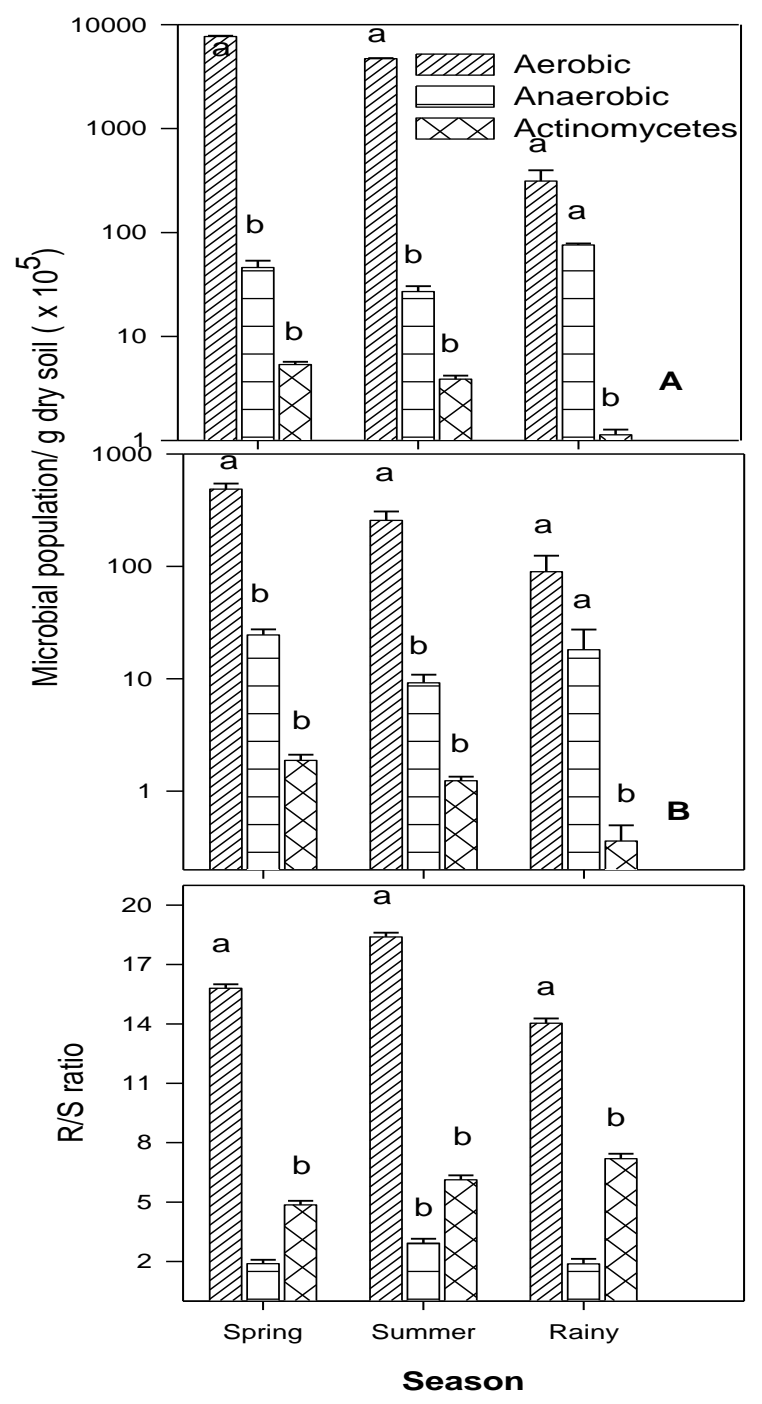


Fig.2 Aerobic bacterial population at different plant growth stages in rhizosphere of Momordica charantia

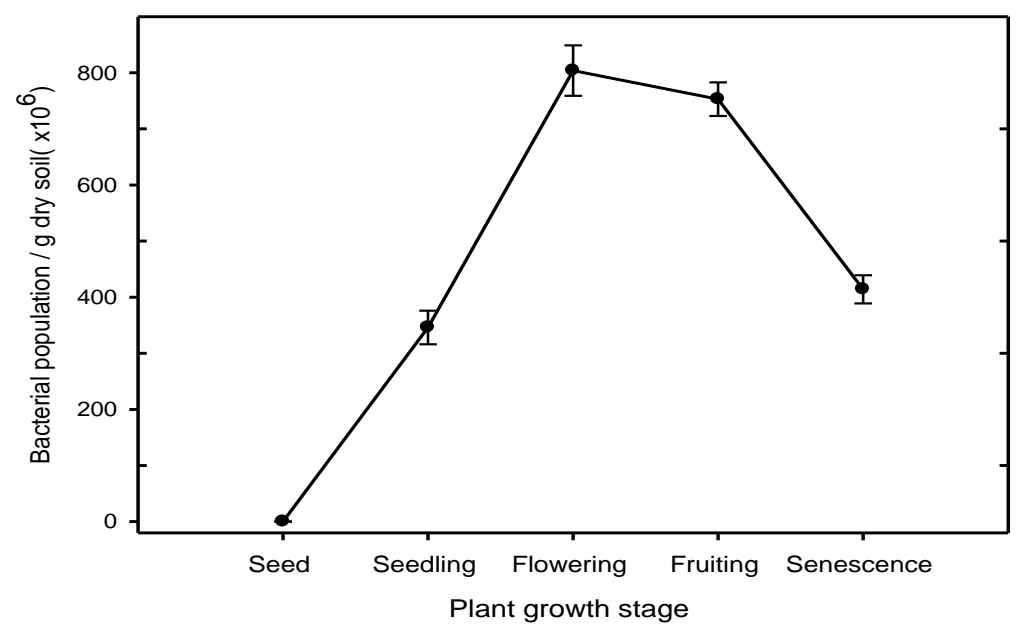

Fig. 3 (A) Aerobic bacterial population, (B) Variation in R/S ratio, at different depth along root length. Letters a, b, c, d and e showed difference based on Tukey HSD
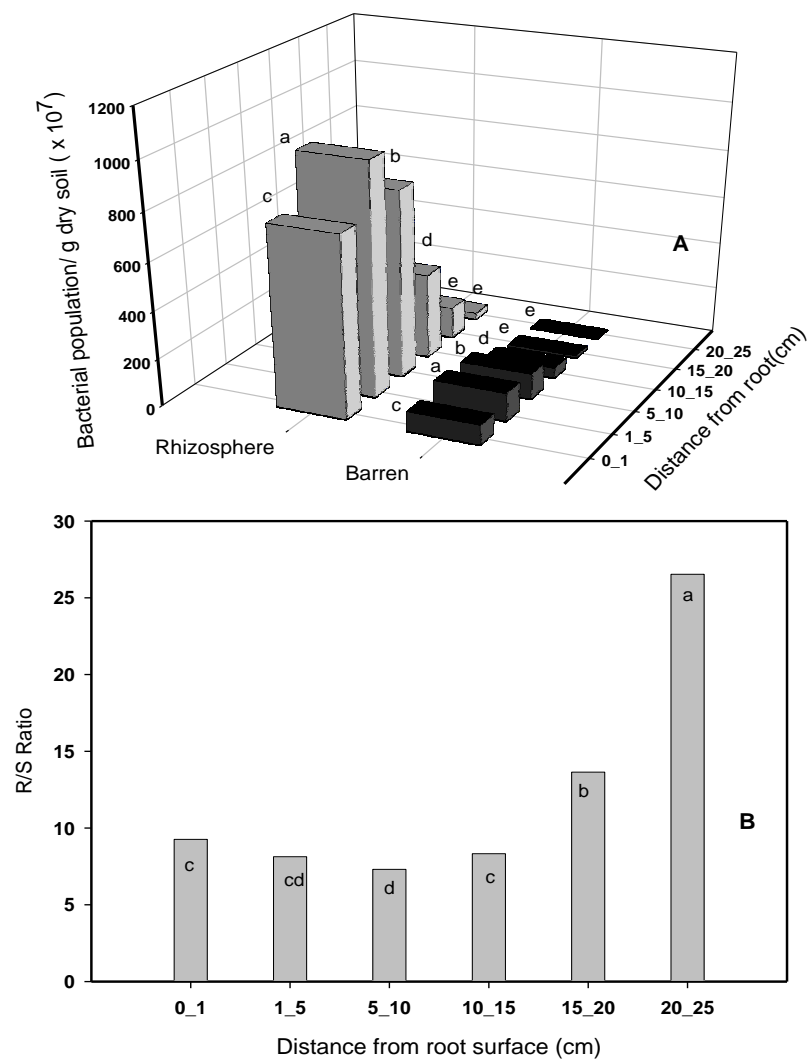
Fig. 4 Cluster analysis of bacterial population (Rescaled Distance cluster) at different root zone in vertical profile in rhizosphere
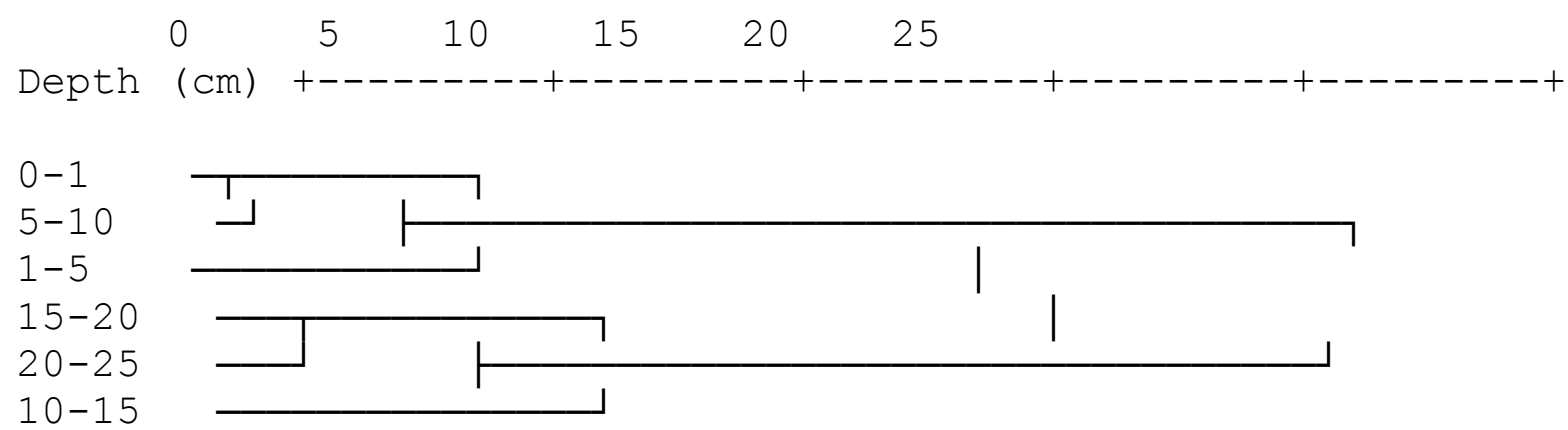

Fig.5 Border cells released at different root developmental stages (lengths).

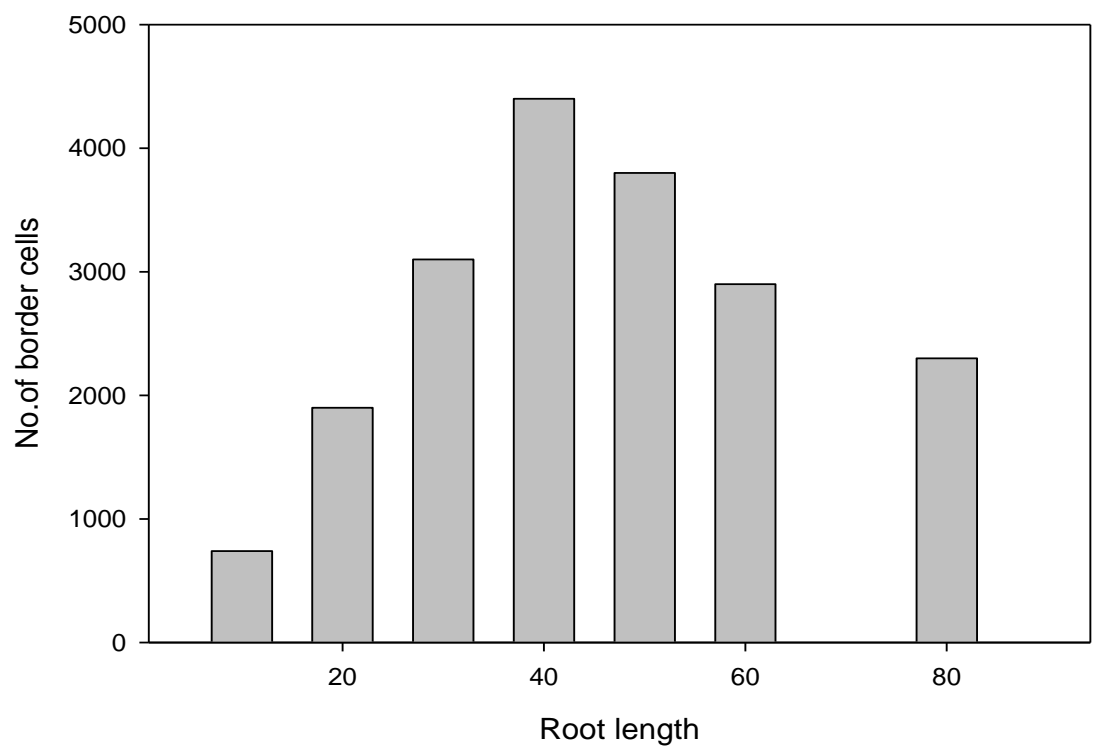

It is noteworthy that the different transects of the root had different population, and it is possible that different root zone transect liberate differential concentration of root exudates. The microbial counts are generally higher in the surface soil layer as compared to the lower depths (Shamir and Steinberger, 2007).

In conclusion, root exudates attract and promote the growth of microorganisms in the rhizosphere and microorganisms and their products interact with the plants in various ways. The growth and community structure of culturable aerobic/anaerobic bacteria and actinomycetes differed significantly during the seasons. Although the maximum population of bacteria in upper surface soil gradually decreased along the soil profile, the $\mathrm{R} / \mathrm{S}$ ratio was near the root tip indicating the significance of sloughed cells in rhizome to support the bacterial population. Our results on root border cell also supported this concept. 


\section{Acknowledgement}

Authors are thankful to University Grant Commission, New Delhi for financial assistance and Head, Department of Botany to providing lab facilities.

\section{References}

Ambardar, S., Vakhlu, J. 2013. Plant growth promoting bacteria from Crocus sativus rhizosphere. World J. Microbiol. Biotechnol., 29: 2271-2279.

Atlas, R., Bartha, R. 2000. Microbial Ecolo., New York. Addison Wesley. Longman.

Bakker, P.A., Berendsen, R.L., Doornbos, R.F., Wintermans, P.C., Pieterse, C.M. 2013. The rhizosphere revisited: root microbiomics. Front Plant Sci., 4: 1-7.

Blume, E., Bischoff, M., Reicher, J.M., Moorman, T., Konopka, A., Turco, R.F. 2002. The Rhizosphere Surface and subsurface microbial biomass, community structure and metabolic activity as a function of soil depth and season. Appl. Soil Ecol., 20: 171-181.

Brimecombe, M.J., De Lel, j F.A., Lynch, J.M. 2001. The Effect of Root Exudates on Rhizosphere Microbial Populations. In: R Pinton, Z. Varanini, P Nannipieri (ed) The Rhizosphere. Biochemistry and Organic Substances at the Soil-Plant Interface. Marcel Dekker, New York. pp 95-140.

Cannesan, M.P., Gangneux, C., Lanoue, A., Giron, D., Laval, K., Hawes, M., Driouich, A., Gibouin, M.V. 2011. Association between border cell responses and localized root infection by pathogenic Aphanomyces euteiches. Annal. Bot., Doi: 10.1093/aob/mcr177.

Curl, E.A., Truelove, B. 1986. The Rhizosphere. Springer-Verlag. New York

Doornbos, R., Loon, L., Bakker, P.H.M. 2012. Impact of root exudates and plant defense signaling on bacterial communities in the rhizosphere. A review. Agron. Sust. Dev., 32: 227-243.
Doumbou, C.L., Hamby-Salove, M.K., Crawford, D.L., Beaulieu, C. 2002. Actinomycetes, promising tools to control plant diseases and to promote plant growth. Phytoprotection, 82: 85-102

Dutta, R.K., Agrawal M. 2001. Litterfall, litter decomposition and nutrient release in five exotic plant species planted on coalmine spoils. Pedobiologia, 45: 298- 312

Glick, B.R. 2014. Bacteria with ACC deaminase can promote plant growth and help to feed the world. Microbiol. Res., 169: 30-39.

Gonalzo- Franco, A.C., Robles- Hernandez, L., Nunez- Barrios, J.L., Crawford, D.L. 2009. Molecular and cultural analysis of seasonal actinomycetes in soils from Artemissia tridentata habitat. ФYTON.78:83- 90.

Hamamoto, L., Hawes, M.C., Rost, T.L. 2006. The production and release of living root cap border cells is a function of root apical meristem type in dicotyledonous angiosperm plants. Annal. Bot., 97: 917923.

Jackson, M.L. 1967. Soil Chemical Analysis. Prentice Hall, London.

Karthikeyan, B., Jaleel, C.A., Lakshmanan, G.M., Deiveekasundaram, M. 2008 Studies on rhizosphere microbial diversity of some commercially important medicinal plants. Colloids Surface and Biointerfaces, 62: 143-145.

Latour, A., Corberand, T., Laguerre, G., Allard, F., Lemanceau, P. 1996. The composition of fluorescent pseudomonas population associated with roots is influenced by plant and soil type. Appl. Environ. Microbiol., 62: 2449- 2456.

Maier, R.M., Pepper, I.L., Gerba, C.P. 2009. Environmental Microbiology $2^{\text {nd }} \quad(e d$. Academic Press. London.

Marschner, P., Yang, C.H., Lieberei, R., Crowley, D.E. 2001. Soil plant specific effects on bacterial community composition in the rhizosphere. Soil Biol. Biochem., 33: 1437-1445.

Marschner, P., Günter, N., Angelika, K., Laure, W., Reinhard, L. 2002. Spatial and 
temporal dynamics of the microbial community structure in the rhizosphere of cluster roots of white lupin (Lupinus albus L. Plant Soil, 246: 167-174.

Murashige, T., Skoog. 1962. A revised medium for rapid growth and bioassays with tobacco cultures. Physiologia Plantarum, 15: 473-497.

Odell, R.E., Matthew, R.D., Danial, S., Wendy, K.S. 2008. Stage- dependent border cell and carbon flow from roots to rhizosphere. Am. J. Bot., 95: 441- 446.

Oku, S., Komatsu, A., Tajima, T., Nakashimada, Y. and Kato, J. 2012. Identification of chemotaxis sensory proteins for amino acids in Pseudomonas fluorescens Pf0-1 and their involvement in chemotaxis to tomato root exudate and root colonization. Microb. Environ., 27: 462-469.

Parez-Montano, F., Jimenez-Guerrero, I., Del Cerro, P., Baena-Ropero, I., LopezBaena, F.J. 2014. The Symbiotic Biofilm of Sinorhizobium fredii SMH12, Necessary for Successful Colonization and Symbiosis of Glycine max cv Osumi, s Regulated by Quorum Sensing Systems and Inducing Flavonoids via NodD1. PLoS ONE, 9:105901.

Shamir, I., Steinberger, Y. 2007. Vertical distribution and activity of soil microbial population in a sandy desert ecosystem. Microbial. Ecol., 53: 340- 347.

Shukla, P.N. 2009. Diversity and Characteristics of Methylotrophs from a degraded Coal mine area. Ph.D Thesis. Banaras Hindu University, India.

Smalla, K., Wieland, G., Buchner Zock, A., Parzy, J., Kaiser, K., Roskot, N., Heuer, G., Berg, G. 2001. Bulk and rhizospheric soil bacterial communities studied by denaturing gradient gel electrophoresis: plant- dependent enrichment and seasonal shifts revealed. Appl. Environ. Microbiol., 67: 4742- 4751.

Walker, T.S., Bais, H.P., Grotewold, E., Vivanco, J.M. 2003. Root exudation and rhizosphere biology. Plant Physiol., 132: 44-51.

Weinert, N., Meincke, R., Gottwald, C., Heuer, H., Gomes, N.C.M. 2009. Rhizosphere communities of genetically modified Zeaxanthin - accumulating potato plants and their parent cultivar differ less than those of different potato cultivars. Appl. Environ. Microbiol., 75: 3859-3865.

Wen, F., Van Effen, H.D., Tsaprailis, G., Hawes, M.C. 2007. Extracellular proteins in pea root tip and border cell exudates. Plant Physiol., 143: 773-783.

\section{How to cite this article:}

Ritu Singh, Ajay Kumar, Monika Singh, Vandana, Satendra Kumar Maurya and K.D Pandey. 2017. Microbial Diversity in the Rhizosphere of Momordica charaentia L. Bitter Gourd. Int.J.Curr.Microbiol.App.Sci. 6(2): 67-76. doi: http://dx.doi.org/10.20546/ijcmas.2017.602.009 